\title{
Financial Integration, Macroeconomic Volatility And Economic Growth In The East African Community
}

\author{
Onesmus Mutunga Nzioka
}

University of Nairobi, Kenya

Prof. Erasmus Kaijage

Professor, School of Business, University of Nairobi, Kenya

Dr. Duncan Elly Ochieng

Lecturer, School of Business, University of Nairobi, Kenya

doi: 10.19044/esj.2017.v13n19p317 URL:http://dx.doi.org/10.19044/esj.2017.v13n19p317

\begin{abstract}
This study aimed at determining the moderating effect of macroeconomic volatility on the relationship between financial integration and economic growth in the EAC.

The study adopted a positivistic research philosophy and casual research design.. Generalized-two stage least squares instrumental variable regression model (G2SLSIV) was then conducted to test the hypothesis. The findings of the study showed that, macro-economic volatility does not have a significant moderating effect on the relationship between financial integration and economic growth. Therefore, the study recommends that, the governments of respective member states work on a monetary policy that aims to attain a single digit level of inflation rate (low inflation targeting), in the spirit of macro-economic convergence. The study culminates with acknowledging the limitations encountered and provides suggestions for further research.
\end{abstract}

\section{Keywords:}

\section{INTRODUCTION}

\subsection{Background to the Study}

International financial integration occurs when exchange controls are removed and the capital account is freed to allow financial resources to flow freely in and out of the country. With the increased degree of international financial integration around the world, many countries especially developing countries are now trying to remove cross-border barrier and capital control, relaxing the policy on capital restrictions and deregulating domestic financial system.Trichet (2005) argues that, financial integration fosters financial development, which in turn creates potential for higher economic growth. 
Financial integration enables the realization of economies of scale and increases the supply of funds for investment opportunities. The actual integration process also stimulates competition and the expansion of markets, thereby leading to further financial development. In turn, financial development can result in a more efficient allocation of capital as well as a reduction in the cost of capital. At the same time, financial integration is blamed for increasing a country's vulnerability to international financial crises, which tend to occur during periods of sudden reversals in international capital flows.

The objective of the East African Community (EAC) is inspired by the interest of the member states of Burundi, Uganda, Rwanda, Kenya and Tanzania to improve the standard of living of the population. This is to be achieved through increased competitiveness, value addition in production, trade and investment. It is through improving the standard of living of its people that, sustainable development of the envisaged economic bloc can be promoted. EAC sees regional financial cooperation as a means of promoting intra-regional trade and exploiting economies of scale by pooling small and fragmented domestic markets to support industrialization (Kasekende and Ng’eno, 2000).

\subsection{Research Problem}

Barro (2001) revealed that, financial instability leads to drops in economic growth. This weak growth is the result of excessive capital inflows and outflows and, more generally, the instability of net financial flows (Prasad et al., 2003; World Bank, 2000) and IMF, 2001). Indeed, financial instability can also impact on the poverty level and have other consequences for the social situation (World Bank, 2000). A stable macroeconomic environment therefore, represents a substantial fundamental pillar of a longterm economic growth. Jeanne (2004) argues that, macroeconomic volatility in developing countries is also worsened by the international contagion phenomenon. Though not directly linked, it has been proved that countries which are more open to trade are also more open financially (Lane, 2000); Heathcote and Perri (2004).

The pursuit of financial integration by the East African community member states with a view to maximizing the ability of financial sectors to mobilize resources and efficiently allocate them to productive sectors of the region, is a key pillar to financial sector development. The East African community leadership has taken this path to pursue sustainable development. However, the frequent experience of macroeconomic volatility which is one of the basic features of developing economies has to be managed. This is so because, the experience is professed to have detrimental effects on long term economic growth and development (Calderon and Schmidt-Hebbel, 2008). 
Existing studies have not clearly indicated the moderating effect of macroeconomic volatility on economic growth (Krugman, 1993) and Razin and Rose,1994). Kose et al (2003a) examined the impact of financial integration on macro-economic volatility but did not consider what moderating effect macro-economic volatility would have on the relationship between financial integration and economic growth. From the East African context, studies exist on the direct relationship between financial integration and economic growth of the East African community. (Njoroge, 2010; Muthoga et al, 2013 and Elly, 2014). However, there is no known study which captures the moderating effect of macro-economic volatility in this context. These conceptual and contextual gaps lead to the following research question: What is the moderating effect of macro-economic volatility on the relationship between financial integration and economic growth in the East African community?

\subsection{Research Objective}

To determine the moderating effect of Macro-economic volatility on the relationship between financial integration and economic growth in the EAC.

\section{EMPIRICAL LITERATURE REVIEW}

Easterly, Islam and Stiglitz (2001) explore the sources of macroeconomic volatility using data for a sample of 74 countries over the period 1960-1997. They find that, a higher level of development of the domestic financial sector is associated with lower volatility. On the other hand, an increase in the degree of trade openness leads to an increase in the volatility of output, especially in developing countries. Their results indicate that, neither financial openness nor the volatility of capital flows has a significant impact on macroeconomic volatility.

O’Donnell (2001) examines the effect of financial integration on the volatility of output growth over the period 1971-1994 using data for 93 countries. He finds that, a higher degree of financial integration is associated with lower (higher) output volatility in OECD (non-OECD) countries. His results also suggest that, countries with more developed financial sectors are able to reduce output volatility through financial integration.These studies fail to address the issue of whether output volatility has any influence on economic growth. It also does not examine the effect of financial integration on economic growth.

Rajmund et al. (2015) examined the relationship between international financial integration and output fluctuation by conducting an analysis on a large sample of developed and developing countries over the past 40 years. They followed the approach employed by Kose et al. (2003) 
and used cross-sectional median of financial liberalization to subdivide developing economies into two groups: more financially liberalized (MFL) and less financially liberalized (LFL) economies. Their results indicated that, while the volatility of output growth rates experienced a decreasing trend over time, financial integration had a significant contribution to output fluctuations. However, the relationship was stronger in developing countries.

Martin and Rogers (2000), found a significant and quantitatively important negative relation between growth and the amplitude of the business cycle whether measured by the standard deviation of growth or the standard deviation of unemployment. However, this relation does not work through an impact of short-term instability on the level of investment in industrialized countries. This could be a natural explanation of the empirical results.

Hnatkovska and Loayza (2003), conclude that macroeconomic volatility and long-run economic growth are negatively related. This negative link is exacerbated in countries that are poor, institutionally underdeveloped, undergoing intermediate stages of financial development, or unable to conduct countercyclical fiscal policies. On the other hand, the volatility-growth association does not appear to depend on a country's level of international trade openness.

Aizenman and Pinto (2005) and Wolf (2005) point out that, in the case of imperfect financial markets, the State and individual households are unable to protect themselves fully against risks which affect their revenue and adjust their consumption to the vagaries of economic activity. The result is that, volatility driven by external factors, for example in relation to terms of trade, generates internal volatility in relation to consumption, particularly in developing countries (Aguiar and Gopinath, 2007; Loayza et al, 2007).

Mougani (2012) provided an empirical analysis of some of the impacts of international financial integration on economic activity and macro-economic volatility in African countries. The results showed that, the impact of external capital flows on growth seems to depend mainly on the initial conditions and policies implemented to stabilize foreign investment, increase domestic investment, productivity and trade, develop the domestic financial system, expand trade openness and other actions aimed at stimulating growth and reducing poverty.

Rajmund and Aneta (2014) examined the relationship between international financial integration, volatility of financial flows and macroeconomic volatility. They content that, examination of the international financial integration and its effects on macroeconomic volatility or stability is particularly important due to existence of generally expected positive relationship between macroeconomic volatility and economic growth, common trends of decreased macroeconomic instability worldwide 
and occurrence of negative sides of financial integration - financial crises. Following their results, they suggest that, relationship between financial integration, volatility of financial flows and macroeconomic volatility is positive, however not significant. Moreover the relationship is stronger in case of developing countries.

\section{Summary of Literature Review and Research Gaps}

Existing studies have not clearly indicated the moderating effect of macroeconomic volatility on economic growth (Krugman, 1993) and Razin and Rose,1994). Kose et al (2003a) examined the impact of financial integration on macro-economic volatility but did not consider what moderating effect macro-economic volatility would have on the relationship between financial integration and economic growth. From the East African context, studies exist on the direct relationship between financial integration and economic growth of the East African community. (Njoroge, 2010; Muthoga et al, 2013 and Elly, 2014). However, there is no known study which captures the moderating effect of macro-economic volatility in this context.

\section{RESEARCH METHODOLOGY}

\subsection{Research Philosophy}

This study applied the positivism research philosophy because it is based on existing theory and it formulated quantitative hypotheses that were tested. The positivist paradigm allowed for deriving the relationship between financial integration, Macro-economic volatility and Economic growth in the EAC. Borrowing from existing literature, the theoretical relationship among the three variables above was hypothesized/formulated in form of an objective. To achieve this objective, appropriate measures for each variable were identified, data was collected and subjected to inferential statistical analysis. Inferential statistical analysis was conducted to establish the significance of the relationship.

\subsection{Research Design}

This study is based on the causal research design. The causal survey design seeks to establish the cause and effect relationship between two or more variables. Causal effect (nomothetic perspective) occurs when variation in one phenomenon, an independent variable, leads to or results, on average, in variation in another phenomenon, the dependent variable. However, conclusions about causal relationships are difficult to determine due to a variety of extraneous and confounding variables that exist in a social environment. This means causality can only be inferred, never proven. 


\subsection{Population of the Study}

The East African Community (EAC) is the regional intergovernmental organization of the Republics of Burundi, Kenya, Rwanda, the United Republic of Tanzania, and the Republic of Uganda, with its headquarters in Arusha, Tanzania. All these republics are technically referred to as the five member/partner states in the EAC. For inclusivity, the population of interest was all the five partner states in the EAC. Together as an economic bloc, the member states were used as the unit of analysis in this study, simply because, the main focus was on financial integration and economic growth of the East African community.

\subsection{Data Collection}

The study used secondary data for the period 1963 to 2014. Annual data on gross capital flows, broad money supply (M2), inflation, exchange rates, Annual GDP figures, growth rate in GDP per capita and total credit to the private sector was retrieved from the East African community secretariat, the international monetary fund and the world bank.

\section{Data Analysis}

The study utilized the generalized two-stage least square (G2SLS) random-effects instrumental variable method (REIVM). Diagnostic tests were carried out to meet the requirements for conducting regression analysis on panel data. These include; Multicollinearity tests, Im- Pesaran-Shit Test (IPS) panel unit root test and Hausman test for fixed effects and random effects models.

\subsection{Multicollinearity Test}

Multicollinearity test was conducted to establish the possibility and extent of linear dependence between the study variables. The results presented in Table 4.1 below shows that, the mean variance inflation factor (VIF) was estimated at 1.47, which is greater than the critical value of 1 . Thus, a VIF of 1.47 tells us that, the variance) of a particular coefficient is $47 \%$ larger than it would be, if that predictor was completely uncorrelated with all the other predictors. As indicated in Table 4.1, no VIFs were greater than 10. This demonstrates absence of strong multicollinearity. In addition, the variables with high VIFs are private bank credit to GDP and M2/GDP which are control variables, and the variables of interest do not have high VIFs. Hence we can safely ignore multicollinearity. 
Table 4.1: Variance Inflation Factor (VIF) Test for Multicollinearity

\begin{tabular}{|l|c|c|}
\hline Variable & VIF & 1/VIF \\
\hline Private Bank Credit to GDP & 2.02 & 0.4955 \\
\hline M2/GDP & 1.79 & 0.5589 \\
\hline Gross capital flow to GDP & 1.58 & 0.6313 \\
\hline Exchange rate volatility & 1.13 & 0.8852 \\
\hline GDP per capita volatility & 1.1 & 0.9050 \\
\hline Inflation volatility & 1.02 & 0.9776 \\
\hline Mean VIF & $\mathbf{1 . 4 7}$ & \\
\hline
\end{tabular}

Author: Researcher (2017)

\subsection{Unit Root Test}

Before estimating the different models to address the study objectives, panel unit root test was first conducted to establish whether there were any variables in the model that were non-stationary. The Im- Pesaranshin Test (IPS) panel unit root test was conducted. The IPS estimates the ttest for unit roots in heterogenous panels (Wicks-Lim, 2005).Table 4.5 gives the summary of the unit root test based on the IPS Test.

Table 4.2: IPS Panel Unit Root Tests

\begin{tabular}{|l|l|l|r|}
\hline & \multicolumn{3}{|c|}{ t-bar Statistic } \\
\hline Variable & Levels & $\begin{array}{l}\text { First } \\
\text { differenc } \\
\text { e }\end{array}$ & $\begin{array}{l}\text { Levels with } \\
\text { time trend }\end{array}$ \\
\hline Gross capital flows to GDP (Financial openness) & -1.9586 & $-9.6123^{*}$ & $-2.8170^{*}$ \\
\hline M2/GDP (Financial Deepening 1) & $-2.4817^{*}$ & $-9.6148^{*}$ & $-3.5410^{*}$ \\
\hline $\begin{array}{l}\text { Private Bank Credit to GDP } \\
\text { (Financial Deepening 2) }\end{array}$ & -0.6178 & - & $-2.2957^{*}$ \\
\hline GDP Per capita volatility & -2.0085 & $-4.7559^{*}$ & $-2.2944^{*}$ \\
\hline Inflation volatility & $-4.9621^{*}$ & $-9.5239^{*}$ & $-5.0659^{*}$ \\
\hline Exchange rate volatility & -0.9297 & $-4.4846^{*}$ & -1.7075 \\
\hline & & - & $-5.8813^{*}$ \\
\hline & $-5.2093^{*}$ & $10.6814^{*}$ & \\
\hline
\end{tabular}

* denotes statistical significance at the 5 percent level

Author: Researcher (2017)

In the test results presented in Table 4.2, gross capital flows to GDP was non-stationary in levels. Similarly, the ratio of private bank credit to GDP was also non-stationary at levels. In addition, two measures for macroeconomic volatility namely GDP per capita volatility and exchange rate volatility were also non-stationary at levels. However, after including a time trend gross capital flows to GDP, private bank credit to GDP, and GDP per capita volatility attained stationarity, showing that the three variables were trend stationary. Furthermore, all the non-stationary variables became stationary upon conducting the first difference of the variables. 


\subsection{Hausman Test}

Statistically, estimation of a fixed effects model is always a reasonable thing to do in panel data estimation. This is because fixed effects models give consistent results such that, as the sample size increases indefinitely, the estimated parameters converge to their true values. The fixed effects models may, however, not be the most efficient (have minimum variance) model to run. Random effects will give better P-values (higher chances of finding that various policy options do influence economic growth) as they are a more efficient estimator, so one should run random effects if it is statistically justifiable to do so.

Under the Hausman (1978) test, the null hypothesis is that the coefficients estimated by the efficient random effects estimator are the same as the ones estimated by the consistent fixed effects estimator. The Hausman (1978) test, therefore, checks a more efficient model against a less efficient but consistent model to make sure that, the more efficient model also gives consistent results. A summary of the Hausman (1978) test results are presented in Table 4.3 below.

Table 4.3: Hausman Test for fixed effects and random effects models

\begin{tabular}{|l|r|r|r|}
\hline Economic Growth & Fixed Effects Model & Random Effects Model & Difference \\
\hline Financial openness & 0.3825 & -2.3468 & 2.7292 \\
\hline GDP per capita volatility & \multicolumn{4}{|c|}{$1.07 \mathrm{E}-06$} & $1.10 \mathrm{E}-06$ & $-3.39 \mathrm{E}-08$ \\
\hline Chi-Square Statistic & $\mathbf{0 . 0 3}$ & P-Value & $\mathbf{0 . 9 8 5 1}$ \\
\hline Financial openness & 56.7677 & 54.7599 & 2.0079 \\
\hline Inflation Volatility & $-5.78 \mathrm{E}-03$ & $-5.74 \mathrm{E}-03$ & $-4.09 \mathrm{E}-05$ \\
\hline Chi-Square Statistic & $\mathbf{0 . 7 3}$ & P-Value & $\mathbf{0 . 8 6 6 5}$ \\
\hline Financial openness & 58.4319 & 54.6107 & 3.8211 \\
\hline Exchange Rate Volatility & \multicolumn{4}{|c|}{$9.97 \mathrm{E}-07$} & $1.03 \mathrm{E}-06$ \\
\hline Chi-Square Statistic & $\mathbf{2 . 4 7}$ & P-Value & $\mathbf{0 . 2 9 1 3}$ \\
\hline
\end{tabular}

The test results show that, the Chi-square statistics for the difference were $0.03,0.73$ and 2.47 with corresponding p-values of $0.9851,0.8665$ and 0.2913 respectively. Since the p-values were larger than the critical value of 0.05 , hence the null hypothesis that, the differences in the coefficients are not systematic was not rejected. This means that, the preferred model was the random effects model. Hence the empirical results on hypothesis testing presented below are based on the random effects model.

\section{Hypotheses Testing}

To achieve the set objectives, the following hypothesis was tested. 
Hypothesis: Macro-economic volatility does not have a significant moderating effect on the relationship between financial integration and economic growth.

This involved testing the main effects of the independent variable (gross capital flow to GDP), the moderating variable (each of the three measures of macroeconomic volatility) and the interaction term between gross capital flow to GDP and each of the three measures of macroeconomic volatility on the dependent variable (economic growth). In order to create an interaction term, gross capital flow to GDP and each of the three measures of macroeconomic volatility were multiplied. The creation of a new variable by multiplying the scores of gross capital flow to GDP and each of the three measures of macroeconomic volatility risks creating a multicollinearity problem. To address the multicollinearity problem, which can affect the estimation of the regression coefficients for the main effects, the interactive factors were converted to standardized $(\mathrm{Z})$ scores that have mean zero and standard deviation one. The standardized variables (gross capital flow to GDP and each of the three measures of macroeconomic volatility) were then multiplied to create the interaction variable.

The results of hierarchical multiple regressions predicting economic growth from gross capital flow to GDP, each of the measures of macroeconomic volatility and the interaction between gross capital flow to GDP are reported in models 1a to 1c. In the second step, the interaction term between gross capital flow to GDP and each of the three measures of macroeconomic volatility was entered into the regression equation and tests of the slope was performed as reported in models 2a to 2c. However, the interaction term was not statistically significant $(\mathrm{p}>0.05)$ in all the models, indicating that each of the three measures of macroeconomic volatility has no moderation effect on the relationship between gross capital flow to GDP and economic growth. The results are summarized in tables 4.4, 4.5 and 4.6 below. 
Table 4.4: Financial Integration, GDP per capita volatility and Economic Growth

\begin{tabular}{|l|r|r|}
\hline G2SLS-random-effects IV regression & Model 1a & $\begin{array}{r}\text { Model 2a } \\
\hline \text { Economic growth }\end{array}$ \\
\hline Gross capital flow to GDP & $\begin{array}{r}\text { Coefficient } \\
\text { ( P-Value) }\end{array}$ & $\begin{array}{r}\text { Coefficient } \\
\text { ( P-Value) }\end{array}$ \\
\hline GDP per capita volatility & $-0.029(0.998)$ & $-0.045(0.997)$ \\
\hline $\begin{array}{l}\text { Normalized (Gross capital flow to GDP)* } \\
\text { Normalized (GDP per capita volatility) }\end{array}$ & $0.000(0.361)$ & $0.000(0.448)$ \\
\hline Constant & & $0.080(0.909)$ \\
\hline R-squared: Within & $0.024^{* *}(0.051)$ & $4.025^{*}(0.046)$ \\
\hline Between & 0.0016 & 0.0018 \\
\hline Overall & 0.467 & 0.4641 \\
\hline Chi-square & 0.0042 & 0.0042 \\
\hline Instrumented: & $1.13(0.568)$ & $1.14(0.767)$ \\
\hline
\end{tabular}

Author: Researcher (2017)

Hnatkovska and Loayza (2003), conclude that macroeconomic volatility and long-run economic growth are negatively related. This negative link is exacerbated in countries that are poor, institutionally underdeveloped, undergoing intermediate stages of financial development, or unable to conduct countercyclical fiscal policies.

Table 4.5: Financial Integration, Inflation Volatility and Economic

\begin{tabular}{|l|r|r|}
\hline G2SLS-random-effects IV regression & Model 1b & Model 2b \\
\hline Economic growth & $\begin{array}{r}\text { Coefficient } \\
\text { ( P-Value) }\end{array}$ & $\begin{array}{r}\text { Coefficient } \\
\text { ( P-Value) }\end{array}$ \\
\hline Gross capital flow to GDP & $5.586(0.582)$ & $5.955(0.541)$ \\
\hline Inflation volatility & $-0.005(0.123)$ & $-0.005(0.115)$ \\
\hline $\begin{array}{l}\text { Normalized (Gross capital flow to } \\
\text { GDP)* Normalized (Inflation }\end{array}$ & & $0.108(0.823)$ \\
\hline Constant & $3.466(0.057)$ & $3.395^{* *}(0.052)$ \\
\hline R-squared: Within & 0.0418 & 0.0427 \\
\hline Between & 0.5412 & 0.5106 \\
\hline Overall & 0.0472 & 0.0481 \\
\hline Chi-square & $2.42(0.298)$ & $2.69(0.442)$ \\
\hline Instrumented: & Gross capital flow to GDP \\
\hline
\end{tabular}

Growth

Author: Researcher (2017) 


\section{Table.4.6: Financial Integration, Exchange Rate Volatility and Economic Growth}

\begin{tabular}{|l|r|r|}
\hline G2SLS-random-effects IV regression & Model 1c & Model 2c \\
\hline Economic growth & $\begin{array}{r}\text { Coefficient } \\
\text { ( P-Value) }\end{array}$ & $\begin{array}{r}\text { Coefficient } \\
\text { ( P-Value) }\end{array}$ \\
\hline Gross capital flow to GDP & $4.999(0.596)$ & $2.468(0.822)$ \\
\hline Exchange rate volatility & $0.000(0.808)$ & $0.000(0.923)$ \\
\hline $\begin{array}{l}\text { Normalized (Gross capital flow to } \\
\text { GDP)* Normalized (Exchange rate }\end{array}$ & & $0.228(0.572)$ \\
\hline Constant & $3.209^{*}(0.036)$ & $3.688^{*}(0.045)$ \\
\hline R-squared: Within & 0.0364 & 0.0208 \\
\hline Between & 0.2667 & 0.1730 \\
\hline Overall & 0.0388 & 0.0225 \\
\hline Chi-square & $1.05(0.591)$ & $1.61(0.658)$ \\
\hline Instrumented: & Gross capital flow to GDP \\
\hline
\end{tabular}

Author: Researcher (2017)

\section{Conclusion of the Study}

On the first scenario of the hypothesis, looking at the effect of GDP per capita volatility on economic growth, we fail to reject the hypothesis, indicating that, GDP per capita volatility has no significant influence on the relationship between financial integration and economic growth. We could therefore conclude that, when GDP per capita declines or increases from a given level to a new level, the relationship between financial integration and economic growth remains the same. In other words, GDP per capita volatility does not have a moderating effect on the relationship between financial integration and economic growth. On the second scenario, looking at the influence of exchange rate volatility on the relationship between financial integration and economic growth, we also fail to reject the hypothesis, indicating that, exchange rate volatility has no significant effect on the relationship between financial integration and economic growth. On the third scenario, we also fail to reject the null hypothesis that, inflation volatility does not have a statistically significant effect on the relationship between financial integration and economic growth. The study concludes that, inflation volatility does not have an effect on the relationship between financial integration and economic growth. Overall, the presence of macroeconomic volatility in the EAC economic bloc does not strengthen, weaken or reverse the relationship between financial integration and economic growth. 


\section{Recommendations of the study}

Since the rise in food and fuel prices which has led to higher import bills and significant balance of payment gaps is said to contribute to high volatility of currencies in net importing countries such as Kenya, Tanzania and Uganda, we recommend that, the respective governments work on a monetary policy that aims to attain a single digit level of inflation rate (low inflation targeting), in the spirit of macro-economic convergence.

\section{Limitations of the Study}

There are various challenges that were encountered in the conduct of this study, as a result of the nature of the study, method of analysis, type of data, context as well as time frame. The study was quantitative in nature, narrowing the researcher to focus on only measures that are quantifiable yet a qualitative study or a combination of both would have provided a wider array of variables to be studied, making the research more robust and less biased. A similar challenge was posed by the type of data used. The study applied secondary data only, limiting the degree of the accuracy of the study findings to the accuracy of the data. This explains why reliability and validity tests were not carried out but the researcher used credible sources such as World Bank and IMF to collect the data, in an effort to ensure that, the findings are reasonably reliable.

This study was limited to the East African community as the context, a region that is too small on the global map or even continent wise. Therefore, the findings are basically applicable to the region and can only be relevant on the global map as a foundation for similar but more extensive studies. A bigger context of the study and use of primary data through interviews or questionnaires which captures more information and attributes of different variables would have only been achievable with more financial resources and investing more time on the research.

\section{Suggestions for further research}

The conduct of this study has generated some research gaps which can be filled by further studies in the future. First, the context of this study was the East African community over the period 1963-2014, as a continuous duration. Conducting a comparative study between the old and the new EAC may be necessary in establishing whether the inclusion of Rwanda and Burundi, has had any positive impact (catalyzed) on the level of financial integration and economic growth or even reduced macro-economic volatility. Future research could focus on the African union as an economic bloc which has a bigger mandate than the East African community. Africa as an 
economic bloc is much more significant on the global economy than the East African community, which is a small segment of the continent.

Therefore, focus on enhancing economic integration and economic growth of Africa as an economic bloc is likely to lead to more synergistic benefits to individual countries than the benefits arising from regional integration. A comparative study on the various economic blocs such as ECOWAS and SADC currently existing in Africa is a worthwhile consideration, as well. Such a study is likely to provide useful insights to international investors on which African regions would be top priority areas as investment destinations, based on the established inter-relationships between the four variables analyzed in the current study.

The current study used defacto measures of financial integration and more specifically, gross capital flows. Future studies can apply different indicators of financial integration as well as macro-economic variables and possibly consider using de jure measures of financial integration. Additionally, the use of qualitative data is recommended for purposes of comparing the findings.

\section{References:}

1. Aguiar, A., and G. Gopinath, (2007). Emerging Market Business Cycles: The Cycle Is the Trend, Journal of Political Economy, University of Chicago Press, 115, 69-102.

2. Azeinman, J., and B. Pinto (2005).Overview in J. Azeinmanet B. Pinto, eds. Managing Economic volatility and Crises. Cambridge, Mass.: Cambridge University Press.

3. Barro, R. (2001). Economic Growth in Fast Asia before and After the Financial Crisis, NBER Working Paper No 8330 (Cambridge, Massachusetts: National Bureau of Economic Research).

4. Calderón, C., \& Liu, L. (2003).The direction of causality between financial development and economic growth. Journal of Development Economics, 72, 321-334.

5. Easterly, W. Islam, R. Stiglitz, J., (2001).Shaken and stirred: Explaining Growth Volatility.

6. Elly.D.O. (2014).Effects of market geography and institutional quality on financial markets integration in the East African community.Published PhD thesis.

7. Heathcote, J. \&Perri, F. (2004). The international diversification puzzle is not as bad as you think, Meeting Papers 152, Society for Economic Dynamics.

8. Hnatkovska, V., Loayza, N., (2003).Volatility and Growth. Working Paper, World Bank. 
9. International Monetary Fund (2001).World Economic Outlook, October, World Economic and Financial Surveys (International Monetary Fund, Washington).

10. Jeanne, O. (2004). Why Do Emerging Market Economies Borrow in Foreign Currency? IMF Working Paper 03/177, Washington, DC.

11. Kose, M. Ayhan, Eswar S. Prasad, and Marco E. Terrones, (2003a), "Financial Integration and Macroeconomic Volatility," IMF Staff Papers, 50 (Special Issue), 119-42.

Krugman P. (1993). Lessons from Massachusetts for EMU" in Torres, F. \& Giavazzi, F. (Editors) Adjustment and Growth in the European Monetary Union London: CEPR and Cambridge University Press.

12. Lane P., R (2000). International Investment Position: A Cross Sectional Analysis, Journal of International Money and Finance, 19, 513-534.

13. Martin, P., Rogers, C., (2000). Long-term Growth and Short-term Economic Instability, European Economic Review 44, 359-381.

14. Mougani, G. (2012), An Analysis of the Impact of Financial Integration on Economic Activity and Macroeconomic Volatility in Africa within the Financial Globalization Context, working paper series No 144, African Development Bank, Tunis, Tunisia.

15. Njoroge, L. (2010). The impact of regional integration on economic growth: empirical evidence from COMESA, EAC and SADC trade blocs. American Journal of Social and Management Sciences, 2010, 1(2), 150- 163.

16. O’Donnell, B., (2001), "Financial Openness and Economic Performance” (Unpublished; Dublin: Trinity College).

17. Prasad, E., Rogoff, K., Wei, S., Kose, M., (2003). Effects of Financial Globalization on Developing Countries: Some Empirical Evidence, IMF Occasional Paper No. 220(Washington: International Monetary Fund).

18. Rajmund and Aneta (2014).Financial Integration, Volatility of Financial Flows and Macroeconomic Volatility, MPRA Paper No. 61845, Technical University in Kosice, Slovak Republic.

19. Rajmund et al (2015).Relationship between Financial Integration, Financial Liberalization and Macroeconomic Volatility, MPRA Paper No. 66143, Technical University in Kosice, Slovak Republic.

20. Razin, Assaf and K. Rose. (1994). Growth, the Pro Capital Mobility: The Impact on Consumption,Investment, and Growth, (Cambridge: Cambridge University Press), 48-76.

21. Trichet, J.C. (2005), Financial markets integration in Europe: the $\mathrm{ECB}^{\mathrm{ee}}$ s view, BIS Review, 39: 1-5. 
Wolf, H. (2005) Volatility: Definitions and Consequences. In $J$. Azeinman and B. Pinto, eds. Managing Economic volatility and Crises. Cambridge, Mass.: Cambridge University Press.

World Bank (2000), The Quality of Growth, (World Bank: Washington DC). 